\title{
Students' comments about university teaching: which links with effectiveness models?
}

\author{
Marie Bocquillon \\ Université de Mons. France. \\ marie.bocquillon@umons.ac.be \\ Antoine Derobertmasure \\ Université de Mons. France. \\ antoine.derobertmasure@umons.ac.be \\ Frédérique Artus \\ Université de Mons. France. \\ frederique.artus@umons.ac.be \\ Marc Demeuse \\ Université de Mons. France. \\ marc.demeuse@umons.ac.be
}

Presented: 11/08/2014 | Accepted: 07/11/2014 |Published: 22/12/2015

\section{Resumen}

Este artículo presenta los resultados de un análisis temático de contenido acerca de 550 comentarios creados dentro un proceso de evaluación instruccional en estudiantes de la Universidad de Mons. La investigación buscó si existía relación entre las características del profesor eficaz según los estudiantes analizados y su relación con la literatura científica teniendo en cuenta, en primer lugar, qué se entiende por enseñanza efectiva en la educación primaria y secundaria, y en segundo lugar, la valoración que hace el estudiante de su proceso de enseñanza-aprendizaje en la educación superior. Los resultados de los comentarios del estudiante muestran un doble mayor interés por el proceso de enseñanza- aprendizaje y la gestión de la clase que por las características personales del profesorado (por ejemplo, su sentido del humor).

Palabras clave: educación superior, calidad, evaluación de la enseñanza por parte de los estudiantes, comentarios escritos de los estudiantes, análisis de contenido, enseñanza eficaz.

\section{Resum}

Aquest treball presenta els resultats d'una anàlisi temàtica de contingut sobre 550 comentaris realitzats per estudiants, com a part d'un procés d'avaluació educativa amb estudiants de la Universitat de Mons. Es persegueix establir un vincle entre les principals característiques del professor eficaç vistes pels estudiants i una revisió de la literatura científica contemplant, en primer lloc, l'ensenyament efectiu en l'educació primària i en la secundària, per a passar en segon lloc, a exposar la valoració dels estudiants sobre el procés d'ensenyament- aprenentatge dels seus professors en l'educació superior. Els resultats assenyalen que els comentaris dels estudiants es relacionen en una doble mesura en el procés d'ensenyament-aprenentatge i la gestió de la classe i no tant en les seues característiques personals (per exemple, el sentit de l'humor).

Paraules clau: Educació superior, qualitat, avaluació de l'ensenyament per part dels estudiants, comentaris escrits dels estudiants, anàlisi de contingut, ensenyament eficaç.

\section{Abstract}

This article presents the results of the thematic content analysis of 550 comments written by students as part of the student evaluation of instruction at the University of Mons. It also seeks to establish a link between the characteristics of the effective teacher as seen by students and a review of the literature on, firstly, effective teaching at the primary 
Autumn (July-December 2015) N. 15. Pages. 11

and secondary education, and secondly, student evaluation of instruction in higher education. The results indicate that students' comments relate to the teacher's instruction and class management twice as commonly as to their personal characteristics (e.g. sense of humour).

Key words: higher education, quality, student evaluation of instruction, students' written comments, content analysis, effective teaching.

\section{Introduction}

Although teaching effectiveness and the teacher effect have been the subject of much research (e.g. Bissonnette, Richard, and Gauthier, 2006; Bressoux, 2001; Creemers and Kyriakides, 2008; Ellett and Teddlie, 2003 ; Good and Brophy, 2008; Reynolds, Muijs, and Treharne, 2003; Rivkin, Hanushek, and Kain, 2005; Scheerens and Bosker, 1997; Slavin, 2009; Stronge, 2007; Teddlie and Reynolds, 2000; Wang, Haertel, and Walberg, 1994) in both primary and secondary education, they are relatively absent from work on higher education. This was apparent, for example, when Bedin and Broussal (2012) analysed three hundred papers presented at the recent conferences of the "Association internationale de pédagogie universitaire" (AIPU). By contrast, there are numerous studies focusing on student evaluation of instruction, which has been practised in English-speaking universities since the sixties (Younès, 2007a) and is now becoming increasingly widespread in Europe (Romainville, 2009).

Much research has been made on student evaluation of instruction. They all reach to limits such as the relationship of students' perceptions with the characteristics of an effective teacher without being based on a clear theory about effective teaching. Consequently, student evaluation of instruction is sometimes considered as being "a competition on personality aspects" between university teachers (Aleamoni, 1999). In this article, we tend to question this statement through the content analysis of a sample of written comments made by students from the University of Mons (UMONS, Belgium) responding to one very open question ("What points could be improved?") and seek data linkage between those comments and the findings of research in two areas: effective teaching in primary and secondary schools, and student evaluation of instruction in higher education. We assume that students can be observers (Alava, Clanet \& Trinquier, 1999) and that their observations can help to improve teaching. Indeed, some research show that students' comments are quite useful for teaching improvement purposes thanks to the wealth of information provided (Berthiaume and Sylvestre, 2012; Winer, Di Genova, Vungoc, and Talsma, 2012; Zimmaro, Gaede, Heikes, Shim, and Lewis, 2006). Nonetheless, a systematic content analysis is indispensable to use them in order to reach to a real teaching improvement (Le Duc, Dillenbourg, and Ricci, 2012; Lewis, 2001). For these reasons, our article focuses rather on the content of students' open comments, though most research on the student evaluation of instruction relate to analyses based on answers to closed-ended questions. The primary goal of this paper is to highlight the content of students' comments: which aspects from the teaching-learning situation do they comment most/less? The secondary goal is to compare students' comments from two different faculties (the Faculty of Psychology and Educational Sciences (FPSE) and the Faculty of Engineering (FPMS)) as these students (humanities versus applied sciences), a priori, seem to behave differently when responding to such evaluations (relevant variable identified in earlier research (Kember \& Leung, 2011)). Moreover, contrasted respondents' profiles between students from these two faculties have been highlighted in a related research (Kozlowski, Artus, Derobertmasure \& Demeuse, 2014). First, the theoretical framework and methodology are presented.

\section{Theoretical framework}

\subsection{Model used to code the comments}

The thematic content analysis of student feedback was conducted based on the Derobertmasure and Dehon model of the teaching-learning situation (2012), adapted from the work of researchers who have taken an interest in students' written comments (Alhija and Fresko, 2009; Le Duc, Dillenbourg, and Ricci, 2012; Lewis; Winer, Di Genova, Vungoc, and Talsma, 2012; Zimmaro, Gaede, Heikes, Shim, and Lewis, 2006; Younès, 2007b). Figure 1 shows the model of the teaching-learning situation adapted for the analysis of students' written comments.

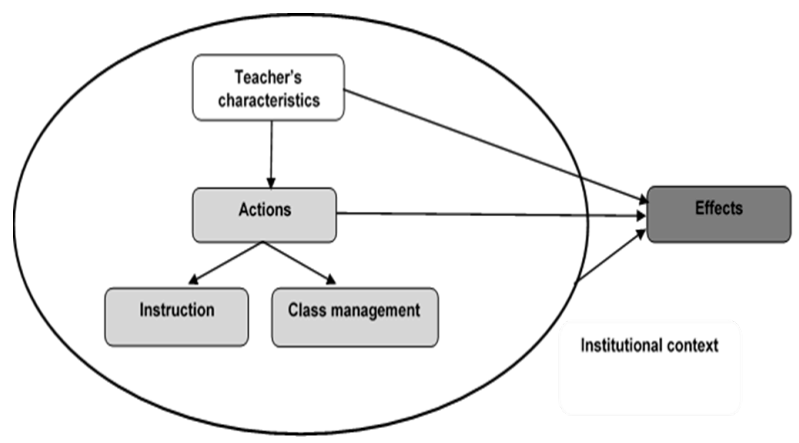

Figure 1. Model of the teaching-learning situation adapted for the analysis of students' written comments.

The model consists of four main categories: the teacher's characteristics, the teacher's actions, the institutional context and the effects perceived by the students.

The teacher's characteristics refer to his or her interpersonal skills and personal traits: students' caring, sense of humour, dynamism of approach to the subject and to teaching, mastery of the material, physical appearance, etc.

The teacher can be engaged in two types of actions: instruction and class management. Instruction relates to:

- the selection and structuring of content;

- clarity of presentation;

- teaching materials; 
- preparation.

Class management actions include:

- communication skills relating to the form rather than to the content of spoken and written discourse (tics, clarity, repetition, errors);

- activities (practical assignments, evaluations and grading criteria, workload);

- management of the working environment and space (general arrangement of students, discipline management, etc.);

- body language;

- management of learning, which concerns what the teacher says or arranges to enable students to learn (methods used, communication of expectations and goals, checking understanding, quality of feedback, etc.);

- pacing and time allocation (the overall time management of a session, time given to the student to complete a task, etc.);

- adaptation to the student's level and profile (prerequisites, prior knowledge, conceptualisations).

The teacher's characteristics and actions are part of a broader institutional context, which includes:

- class timing and length;

- the physical environment (classrooms);

- the number of students enrolled on the course;

- the composition of the 'class group' (profile of students);

- the organisation of the curriculum;

- the equipment provided by the university (computers, microscopes, etc.).

The teacher's characteristics, his actions and the institutional context may have effects regarding:

- learning/understanding;

- motivation/interest;

- participation;

- professional and personal development.

For the purposes of this article on the links between the content of students' written comments and teacher effectiveness literature, we will focus on the categories of "teacher characteristics" and "teacher's actions".

\subsection{Characteristics of the effective teacher in primary} and secondary education

In this section, we link the characteristics of the effective teacher with the various categories in the model of the teaching-learning situation. To do this, we draw on a body of research on effective teaching in primary and secondary education (Bissonnette, Richard, and
Gauthier, 2005; Gauthier, Bissonnette, and Richard, 2013; Merle, 1998 ; Rosenshine, 1997; Creemers, 1994; Slavin, 2009, 2014; Stronge, 2007; Wang, Haertel, and Walberg, 1994). We do this for two reasons. On the one hand, little if any empirical research has been conducted into effective teaching and the teacher effect relating specifically to higher education (Bedin and Broussal, 2012). So, there is no general agreement about what is an effective university teacher (Penny, 2003; Young and Shaw, 1999). Secondly, the general characteristics of the effective teacher are considered by some authors (Allan, Clarke, and Jopling, 2009; Gage, 2009) to be relatively consistent across different educational levels and disciplines. In addition, some characteristics of the effective teacher listed below are also mentioned by Ramsden (2003) and by Prégent, Bernard and Kozanitis (2009) in publications on university teaching.

The following characteristics of the effective teacher can be linked with the "teacher characteristics" category of the model of the teaching-learning situation:

- the effective teacher cares about his/her students, and takes an interest in them and the problems they face;

- he/she treats students with fairness and respect;

- he/she interacts with students, is friendly while remaining professional, and displays a sense of humour;

- he/she demonstrates enthusiasm and motivation with regard to teaching;

- he/she evaluates the effects of his/her teaching (from the point of view of students and from other sources) and feels responsible for the success or failure of his/her students. He/she is aware of his/her strengths and weaknesses and reflects on how to improve his/her teaching and develop professionally.

Likewise, each of the teacher's actions presented in the model of the teaching-learning situation may be associated with what is supposed to make an effective teacher:

- selection and structuring of content: the effective teacher adapts the content to the objectives and to the students' level;

- clarity of presentation: the effective teacher goes back over the prerequisites and what was seen in the previous lesson; provides clear and simple explanations; explains the material step by step; gives examples; frequently recalls the main points;

- teaching materials: the effective teacher prepares teaching materials in advance and adapts them to the students' level;

- preparation: the effective teacher plans his/her classes carefully but not rigidly, in order to leave room for students' reactions and the unexpected. This planning involves defining objectives, structuring the content and preparing questions for the students, choosing teaching strategies and learning activities, 
reflecting on the organisation of time and space and selecting evaluation procedures while keeping in mind the students' characteristics (level of development, attention span, learning styles, etc.);

communication skills: the effective teacher uses precise language, articulates properly and speaks without hesitation;

- activities: the effective teacher offers students a variety of activities of varying levels of complexity (directed exercises followed by feedback; individual exercises; reading; revision; cooperative activities; asking students to explain the material to someone else; to write questions; to answer questions; to structure the material in the form of plans or mind maps; to write summaries; to apply what has been learned to another situation; to give examples, etc.); clearly explains assignments to be done out of class; and adapts the work to the student's level and the course content. Regarding evaluation activities, the effective teacher frequently evaluates learning (formally or informally, with various types of evaluation); and ensures that there is a link between the evaluation and what has been taught to the students;

management of the work atmosphere and space: the effective teacher establishes routines; uses constant discipline; organises space;

- body language: the effective teacher uses gesture and movement to engage students' attention;

- learning management: the effective teacher checks that students have understood and engages their attention by asking questions; varies question types; waits for the student to answer the question instead of answering it him-/herself or asking another student; formulates high and clear expectations; varies teaching strategies and activities available to students; connects his/her teaching with real-life situations; walks around the classroom to supervise students' work; provides immediate, clear and specific feedback, and reinforcement; goes back over material that has not been understood with students;

- pacing: the effective teacher maintains a steady flow of activities. His/her teaching can be described as 'intense', and is characterised by frequent interaction with students and a pace that is sustained, but adapted to the students' level. He/she ensures that students allocate as much time as possible to the task, manages transitions so that they are as short as possible and avoids interruptions;

- adaptation to the student's level and profile: the effective teacher adapts his/her teaching to the students' level, conceptualisations and needs.

\subsection{Research into student evaluation of instruction}

Several empirical studies have shown that student evaluation of instruction is a valid means of assessing teaching effectiveness (Abrami, d'Apollonia, and Rosenfield, 2007; Aleamoni, 1999; Marsh, 1987; Wachtel, 1998). Moreover, its validity is reinforced by several studies that have shown that students' judgments are correlated with other indicators of effectiveness such as teachers' self-evaluations, judgments of teachers' performance by experts, judgments of former students and measures of students' learning (Abrami, d'Apollonia, and Rosenfield, 2007; Aleamoni, 1999; Marsh, 1987; Ramsden, 2003; Wachtel, 1998).

Marsh (1987: 5) highlighted nine factors of effective teaching on the basis of factor analyses conducted on questionnaires completed by students and selfevaluations completed by teachers: "learning value, instructor enthusiasm, organization, individual rapport, group interaction, breadth of coverage, examinations and grading, assignments and readings, and workload difficulty".

For their part, Abrami, d'Apollonia and Rosenfield (2007: 429) highlighted four factors of effective teaching on the basis of a factorial analysis of 17 studies on student evaluation of instruction:

the first (and most important) factor essentially brings together, according to the authors, the characteristics associated with the teacher's educational role: "choice of supplementary materials, relevance of instruction, overall course, monitoring learning, general knowledge and cultural attainment, research productivity and reputation, motivating students to greater effort, enthusiasm for teaching, high-level cognitive outcomes, clarity of instruction, stimulation of interest, preparation, and management style";

- the second factor (which is almost as important as the first) essentially brings together, according to the authors, the characteristics of the teacher as a person: "personal appearance, health, and attire, general attitudes, dramatic delivery, concern for students, vocal delivery, answering questions, knowledge of teaching, tolerance of diversity, availability, overall instructor, interaction and discussion, respect for others, enthusiasm for students, friendly classroom climate, enthusiasm for subject, and personality characteristics";

- the third factor (much less important than the previous two) brings together the characteristics associated with the teacher's role as regulator: "evaluation and feedback";

- the fourth factor (the least important factor and the only one that has no correlation with the others) brings together the following characteristics: "supervision and disciplinary actions, knowledge of domain, choice of required materials, and objectives".

Delaney, Johnson, Johnson, and Treslan (2010) have highlighted nine characteristics of the effective teacher as perceived by students:

"respectful": the effective teacher shows empathy; cares about students' understanding and success; presents his/her expectations clearly; is fair and open-minded;

"knowledgeable": the effective teacher has a thorough knowledge of the content he/she teaches, as well as a variety of teaching and assessment 
strategies; is able to relate the course content to reallife situations;

"approachable": the effective teacher interacts positively with his/her students; creates a positive climate; allows them to ask questions;

"engaging": the effective teacher shows enthusiasm and shares his/her passion with students; uses a variety of teaching strategies and interactive activities; allows students to actively engage in the course;

"communicative": the effective teacher is skilled in active listening; clearly presents the content and evaluation criteria; provides well-organised teaching materials;

"organized": the effective teacher prepares his/her lessons in advance; provides students with clear visual aids and a lesson plan; does not make digressions; optimises the use of teaching time; provides timely and constructive feedback about examinations and assignments;

- "responsive": the effective teacher asks the students questions and gives them prompt and constructive feedback during the lesson; takes account of students' needs and their different learning speeds;

- "professional": the effective teacher is dressed appropriately;

- "humorous": the effective teacher displays a sense of humour.

\section{Methodology}

3.1 Educational surveys conducted at the University of Mons

The results presented are taken from the content analysis of a sample of 550 comments obtained during educational surveys conducted at the University of Mons in 2010-2011. The objective of this evaluation is to gather an overall view on the performance of a teacher. It is an annual evaluation, which takes place in the year following the student's successful completion of the course. It contains a closed question, "How would you rate this teacher's teaching performance overall?", to which the student must respond by selecting from a scale of 5 possible values: "excellent", "good", "satisfactory" "unsatisfactory", "highly unsatisfactory". If the student answers "unsatisfactory" or "highly unsatisfactory", he or she is required to answer the open question, "What points could be improved?" Students who answer "excellent", "good" or "satisfactory" can also write comments, but are not required to do so (Kozlowski, Artus, Derobertmasure, and Demeuse, 2014). It is the answers to this open question that form the subject of the thematic content analysis to be presented in this article.

\subsection{Sampling}

550 comments were selected from the 4,414 comments made by students from the Faculty of Psychology and Educational Sciences (FPSE) ( $N=2,727)$ and the Faculty of Engineering (FPMS) $(\mathrm{N}=1,687)$, which had themselves been selected from a total of 7,428 comments obtained for all the faculties of the University of Mons in educational surveys conducted in 2010-2011. These two faculties were chosen because they differ from a quantitative point of view in several ways (Kozlowski, Artus, Derobertmasure, and Demeuse, 2014).

Firstly, of all the faculties, FPMS had the highest percentage of respondents: $72.90 \%$, compared with $54.29 \%$ for FPSE. Secondly, FPSE is the faculty with the highest percentage of evaluations which include a comment: $42.01 \%$, compared with $14.06 \%$ for FPMS. Thirdly, if we look at the breakdown of comments by level of satisfaction, we find that comments associated with the ratings "good" and "excellent" are more common at FPSE $(67.8 \%$ of the comments made by students at this faculty) than at FPMS $(60 \%$ of comments made by students at this faculty). In addition, comments associated with the "highly unsatisfactory" rating, which are in general very infrequent, are more common at FPMS $(5.9 \%$ of the comments made by students at this faculty) than at FPSE ( $2.4 \%$ of the comments made by students at this faculty) ${ }^{1}$.

It is for this reason that the starting point of the sampling was the selection of all the comments associated with the "highly unsatisfactory" rating for both faculties in 2010-2011, representing a total of 158 comments (Table 1): 63 for FPSE (58 comments by Bachelor's (BA) students and 5 comments by Master's ${ }^{2}$ (MA) students) and 95 for FPMS (78 comments by Bachelor's students and 17 comments by Master's students). Then we randomly selected the same number of comments (58 comments by Bachelor's students from FPSE, 5 comments by Master's students from FPSE, 78 comments by Bachelor's students from FPMS and 17 comments by Master's students from FPMS), from all the comments associated with firstly the "satisfactory" rating and secondly the "excellent" rating on the other. One objective was to select 30 comments made Master's students per rating, but this was not always possible given some very low numbers (5 for FPSE and 17 for FPMS).

\begin{tabular}{|c|c|c|c|c|c|c|c|}
\hline & \multicolumn{2}{|c|}{$\begin{array}{c}\text { Highly } \\
\text { unsatisfactory }\end{array}$} & \multicolumn{2}{|c|}{ Satisfactory } & \multicolumn{2}{|c|}{ Excellent } \\
\hline & & $\begin{array}{c}\text { Total } \\
\text { number }\end{array}$ & $\begin{array}{l}\text { Number of } \\
\text { comments } \\
\text { analysed }\end{array}$ & $\begin{array}{c}\text { Total } \\
\text { number }\end{array}$ & $\begin{array}{l}\text { Number of } \\
\text { comments } \\
\text { analysed }\end{array}$ & $\begin{array}{c}\text { Total } \\
\text { number }\end{array}$ & $\begin{array}{l}\text { Number of } \\
\text { comments } \\
\text { analysed }\end{array}$ \\
\hline \multirow[t]{2}{*}{$\mathrm{F}$} & BA & 58 & 58 & 362 & 58 & 589 & 58 \\
\hline & $\begin{array}{l}\text { MA } \\
\text { and } \\
\text { PY }\end{array}$ & 5 & 5 & 105 & 30 & 193 & 30 \\
\hline $\begin{array}{l}\mathbf{F} \\
\mathbf{P} \\
\mathrm{M} \\
\mathbf{S}\end{array}$ & BA & 78 & 78 & 215 & 78 & 447 & 78 \\
\hline & MA & 17 & 17 & 55 & 30 & 94 & 30 \\
\hline & Total & 158 & 158 & 737 & 196 & 1323 & 196 \\
\hline
\end{tabular}

Table 1. Total number of comments and number of comments analysed in terms of the rating awarded (highly unsatisfactory, satisfactory, excellent) for 20102011.

1 The percentage of comments associated with the "highly unsatisfactory" rating is directly dependent on the number of "highly unsatisfactory" responses, as any student who applies this rating is required to submit a comment.

2 Students from the Preparatory Year (PY) for the Master's

Degree in Education are included as Master's students. 


\subsection{Content analysis and NVivo ${ }^{\circledR}$ software}

Content analysis, although used in many studies, remains difficult to define in a manner that is both comprehensive and consensual (Derobertmasure and Robertson, 2013). Conducting a content analysis of a document means "finding the information in it, identifying the meaning or meanings of what is presented, and formulating and classifying everything that the document contains" (Mucchielli, 2006: 24), with minimal use of intuition and subjectivity (Derobertmasure and Robertson, 2013).

From among several types of content analysis, thematic content analysis was chosen for this study. This type of analysis is based on breaking the text down into units of meaning (Derobertmasure and Dehon, 2012). The researcher is then required to assign a code to each unit of text according to its content.

The NVivo ${ }^{\circledR}$ software package was chosen, because it is frequently used for thematic analysis and its use in social science research is widespread, which seems to give it some validity (Derobertmasure and Robertson, 2013).

\subsection{Putting the theoretical model into practice in a coding grid}

The model of the teaching-learning situation was translated into a coding scheme consisting of eight main categories (actions, effects, teacher characteristics, institutional context, general appreciation, students' feelings, other, illegible). The different sub-categories that interest us in this article (the teacher's different actions) were presented in Section 2.

In the content analysis, each comment $(N=550)$ was broken down into coding units ( $N=1197)$, that is to say the "content segment that can be regarded as the basic unit for categorisation and frequency counting" (Bardin, 2001: 135). The researcher may use a semantic criterion (based on the meaning) or a syntactical criterion (word, sentence, paragraph or message) to determine the coding unit (Derobertmasure and Robertson, 2013). For the purposes of this study, the semantic criterion was chosen to determine the coding units (following several authors such as Alhija and Fresko, 2009; Le Duc, Dillenbourg, and Ricci, 2012; Winer, Di Genova, Vungoc, and Talsma, 2012). This choice is based on the fact that the same comment can relate to more than one theme. For example, here is a comment that relates to three themes, which has therefore been broken down into three units of meaning:

"Complete, clear and understandable notes [teaching material]. The teacher is pleasant [teacher's characteristics] despite the quantity of material covered with him [selection and structuring of content]."

Each coding unit was therefore coded according to its theme, but also according to its polarity ("positive", "negative", "recommendation" or "neutral"):

the "positive" category (42.02\% of the 1,197 units) contains those statements in which students refer to the positive points and strengths in the teacher's performance, without offering suggestions for improvement (e.g. "The course is dynamic and the teacher makes it easy to understand.");
- the "negative" category (47.95\%) contains those statements in which students refer to the negative points and weaknesses in the teacher's performance, without offering suggestions for improvement (e.g. "His course is disorganised and very muddled.");

- the "recommendation" category (5.76\%) contains suggestions of ways to improve, which are often characterised by the use of the conditional (e.g., "More time should also be spent on the exercises.");

- the "neutral" category (2.92\%) contains statements of students who say they are unable to judge the teacher or who do so in a neutral tone (neither positive nor negative) (e.g., "I had him very little, I can't judge.").

If we reuse the previous example, we see that the same comment can contain units with different polarities:

“Complete, clear and understandable notes [positive]. The teacher is pleasant [positive] despite the quantity of material covered with him [negative]".

\subsection{Validation of the coding procedure}

To limit the biases associated with content analysis, such as the subjectivity of the coder, two validation procedures were chosen from those presented by Mukamurera, Lacourse, and Couturier (2006): the operational definition of coding categories and sub-categories and the verification of inter-coder reliability (reproducibility). The latter was calculated using the formula of Miles and Huberman (2003: 126): number of agreements between codings / (number of agreements + number of disagreements between codings). Inter-coder reliability is considered satisfactory at or above a level of agreement of $80 \%$. In this research, 50 units were coded independently by a second researcher using the operational definition of the various categories and subcategories. The result was $94 \%$ agreement on the polarity of units and $78 \%$ agreement on themes. After the discussion of disagreements, the result was $100 \%$ on polarity and $98 \%$ on themes.

\section{Analysis of the results of the entire corpus} 4.1 The two categories that attracted the most comment: the teacher's actions and characteristics

The two most commented-on categories are the teacher's actions $(49.21 \%$ of the 1,197 units) and teacher's characteristics (24.73\% of the 1,197 units). It can thus be seen that students comment twice as often on the teacher's actions as on his/her personal characteristics (e.g. "Really very nice"). Students attribute more importance to the teacher's skilful use of the various instruction and class management actions than they do to his/her interpersonal skills and personal traits (niceness, sense of humour, etc.), which is useful from a formative point of view, as the teacher's behaviour is easier to improve than his or her personal characteristics (Winer, Di Genova, Vungoc, and Talsma, 2012).

The two most commented-on categories (the teacher's actions and characteristics) are the same regardless of the polarity of comments (positive, negative or recommendation). 


\subsection{Focus on the teacher's actions}

Table 2 presents the breakdown of coded units in the "actions" category $(\mathrm{N}=589)$ within the sub-categories (different types of action).

\begin{tabular}{|c|c|}
\hline Clarity of presentation & $198(33.62 \%)$ \\
\hline Management of learning & $105(17.83 \%)$ \\
\hline Activities & $93(15.79 \%)$ \\
\hline Choice and structuring of content & $66(11.21 \%)$ \\
\hline Teaching materials & $46(7.81 \%)$ \\
\hline $\begin{array}{c}\text { Management of pacing and time } \\
\text { allocation }\end{array}$ & $41(6.96 \%)$ \\
\hline Communication skills & $19(3.23 \%)$ \\
\hline Adaptation to students' level and profile & $12(2.04 \%)$ \\
\hline Management of atmosphere and space & $8(1.36 \%)$ \\
\hline Preparation & $1(0.17 \%)$ \\
\hline Body language & $0(0 \%)$ \\
\hline Actions & $\mathbf{5 8 9}(100 \%)$ \\
\hline
\end{tabular}

Table 2. Breakdown of coded units in the "actions" category $(N=589)$ within the sub-categories.

The most commented-on teacher's actions are clarity of presentation (33.62\% of the coded units in the "actions" category), management of learning (17.83\%), activities (15.79\%), choice and structuring of content (11.21\%), teaching materials $(7.81 \%)$ and the management of pacing and time allocation (6.96\%). As illustrated by the sample comments below, the following teacher's actions are important for students:

- choose and structure the content of his/her course ["A good mix of theory and illustrative examples, an interesting variety of topics covered"];

- provide clear explanations and give examples ["Clear explanations, tells us about his work in connection with the course"];

- manage learning, i.e. clearly communicate expectations and goals ["You know exactly what is expected of you during practicals and for the exam"]; manage discussions and check that students have understood ["He always tries to make sure that everyone understands properly. He also gets students to participate in class"]; provide quality feedback ["feedback very poor"];

- set appropriate activities (practical assignments, evaluation tests) ["Very helpful exercise sessions", "His exams are composed of questions which do not relate to the context of the course, which leads to a high failure rate"];

- $\quad$ provide appropriate teaching material ["This course is well illustrated thanks to the videos used"];

- manage the pacing and time allocation ["Pace too fast for you to be able to follow"].

- Conversely, students make little if any reference to the following actions: communication skills (3.23\%) ["His diction makes him a delight to listen to"], adaptation to students' level and profile (2.04\%) [“I have the impression that he thinks we know as much about [name of discipline] as he does"], management of atmosphere and space (1.36\%)
["He does not always succeed in keeping the audience quiet"], preparation (0.17\%) [“The preparation of the course needs to be improved"] and body language $(0 \%)$.

\section{Comparison of comments from the two faculties (FPSE and FPMS)}

If we look at the distribution of units associated with each of the teacher's actions between the two faculties, we find little difference between the comments of students from FPSE and those from FPMS. However, the comments from students at FPSE include more units on "activities" (19.23\% of units coded in "actions, FPSE" (N = 312)) than those from students at FPMS $(11.91 \%$ of units coded as "actions, FPMS" $(\mathrm{N}=277))$. To attempt to provide an explanation for this difference, it is necessary to consider the different activities concerned. This subcategory has been divided into three themes: (1) practical assignments, laboratory work, etc., (2) workload, and (3) evaluation/grading. Table 3 shows the distribution of units coded in the "activities" sub-category according to the faculty and these three themes.

\begin{tabular}{|c|c|c|}
\cline { 2 - 3 } \multicolumn{1}{c|}{} & FPSE & FPMS \\
\hline $\begin{array}{c}\text { Practical assignments, } \\
\text { laboratory work, etc. }\end{array}$ & $11(18.33 \%)$ & $15(45.45 \%)$ \\
\hline Workload & $1(1.67 \%)$ & $2(6.06 \%)$ \\
\hline Evaluation-grading & $48(80 \%)$ & $16(48.48 \%)$ \\
\hline Activities & $60(100 \%)$ & $33(100 \%)$ \\
\hline
\end{tabular}

Table 3. Distribution of units coded in the "activities" subcategory $(N=93)$ according to the faculty and the three themes.

The category "evaluation-grading" is far more prominent in the comments of FPSE students $(80 \%$ of units coded as "activities, FPSE") than in those of FPMS students (48.48\% of units coded as "activities, FPMS"). This can be explained by the fact that FPSE students commented very negatively on certain examinations regarding the relevance of the questions, the teacher's grading, etc. (38 units out of the 48 coded as "FPSE, evaluationgrading" are negative units).

As the following quotations illustrate, it seems that the effective teacher, in the view of FPSE students, uses evaluation methods properly, sets evaluation activities which are consistent with the course content and grades the students fairly. Incidentally, the importance of a fair grade is also raised by some students at FPMS.

"Moreover, I don't think that exams using a true /false format with negative grading are a good method, as they cannot demonstrate that we really know the material. Some students, including myself, are caught out by contorted phrasing despite knowing the subject matter very well. Open questions would be more useful" [Bachelor's student, FPSE]

"His exam isn't clear (the presentation of the questions on the sheet and the multiple choice). There is no consistency " [Bachelor's student, FPSE] 
"Questions in the exam on material that we have never seen!" [Bachelor's student, FPSE]

"The criteria for evaluation and correction are too vague" [Bachelor's student, FPSE]

"The multiple choice questions are a lottery! Playing with words is useless for evaluating a student!" [Master's student, FPSE]

"His exam is demanding, but fair" [Bachelor's student, FPSE]

"Not always fair in the grading of the orals" [Bachelor's student, FPMS]

It is interesting to note that students criticise evaluations when they bear no relation to the course content or when the grading is not fair, but also when they regard them as too "easy". Some students highlight the importance of setting evaluation activities that are suited to their level and that require them to implement skills at a sufficiently high level:

"But the evaluation is at such a low level that it is really easy to pass" [Master's student, FPSE]

"Because passing the course does not require any form of reflection, as the exam consists purely of regurgitating material learnt by heart." [Master's student, FPMS]

For its part, the category "practical assignments and lab work" is commented on more frequently by the students at FPMS $(45.45 \%$ of units coded as "activities, FPMS" compared with $18.33 \%$ for FPSE). These results are doubtless related to the fact that activities of the "lab work" type are not organised at FPSE. As the following quotations illustrate, the effective teacher, in the view of students at FPMS, is able to adapt the difficulty of exercises to the students' level, conduct exercise sessions properly (answer questions, not make mistakes, set enough exercises, allow sufficient time for the exercises, etc.). In addition, one FPSE student highlights the importance of setting a variety of activities.

"Exercise sessions in the second term should be completely overhauled (mistakes, no answers to questions)" [Bachelor's student, FPMS]

"More time should also be spent on the exercises." [Bachelor's student, FPMS]

"One shortcoming is the relative lack of exercises" [Bachelor's student, FPMS]

"Only does those [exercises] to which we have the answers" [Bachelor's student, FPMS]

"Lab work impossible to complete" [Master's student, FPMS]

"The exercise sessions in [course name] lead to a real understanding of the course" [Master's student, FPMS] "Diversity of activities" [Master's student, FPSE]

\section{Discussion}

The themes most commented on are the teacher's actions (49.21\% of units) and teacher's characteristics (24.73\%). Students therefore comment twice as often on what the teacher does as on his/her personal characteristics. The fact that the evaluation of teaching by students is not a "popularity contest" in which the "winner" is the nicest teacher had already been highlighted by Aleamoni (1999) and Le Duc, Dillenbourg and Ricci (2012). Students therefore attach great importance to instruction and class management as characteristics of effective teaching. These results confirm that effective teaching is multidimensional (Marsh, 1987): it is characterised by numerous and varied actions (Abrami, Apollonia, and Rosenfield, 2007). Table 4 shows the correspondence between the characteristics of the effective teacher identified in (1) research into effective teaching in primary and secondary education, (2) research into student evaluation of instruction; (3) this study.

\begin{tabular}{|c|c|c|c|c|c|c|}
\hline \multicolumn{2}{|c|}{$\begin{array}{l}\text { Characteristics of the } \\
\text { effective teacher }\end{array}$} & $\begin{array}{l}\text { Research } \\
\text { into effective } \\
\text { teaching in } \\
\text { primary and } \\
\text { secondary } \\
\text { education } \\
\text { (synthesis) }\end{array}$ & $\begin{array}{l}\text { Marsh } \\
(1987)\end{array}$ & $\begin{array}{c}\text { Abrami, } \\
\text { d'Apollonia, } \\
\text { and } \\
\text { Rosenfield } \\
(2007)\end{array}$ & $\begin{array}{l}\text { Delaney } \\
\text { et al. } \\
(2010)\end{array}$ & $\begin{array}{l}\text { This } \\
\text { study }\end{array}$ \\
\hline \multicolumn{2}{|c|}{$\begin{array}{c}\text { Choice and structuring } \\
\text { of content }\end{array}$} & $x$ & $x$ & $x$ & $x$ & $x$ \\
\hline \multicolumn{2}{|c|}{ Clarity of presentation } & $x$ & $x$ & $x$ & $x$ & $x$ \\
\hline \multicolumn{2}{|c|}{ Teaching materials } & $x$ & & & $x$ & $x$ \\
\hline \multicolumn{2}{|c|}{ Preparation } & $x$ & $x$ & $x$ & $x$ & \\
\hline \multicolumn{2}{|c|}{ Communication skills } & $x$ & & $x$ & & \\
\hline \multirow[t]{2}{*}{ Activities } & $\begin{array}{l}\text { Activities } \\
\text { set }\end{array}$ & $x$ & $x$ & & $x$ & $x$ \\
\hline & $\begin{array}{l}\text { Evaluation } \\
\text { activities }\end{array}$ & $x$ & $x$ & $x$ & $x$ & $x$ \\
\hline \multicolumn{2}{|c|}{$\begin{array}{c}\text { Management of } \\
\text { working atmosphere } \\
\text { and space }\end{array}$} & $x$ & & & & \\
\hline \multicolumn{2}{|c|}{ Body language } & $x$ & & & & \\
\hline \multicolumn{2}{|c|}{$\begin{array}{l}\text { Management of } \\
\text { learning }\end{array}$} & $x$ & $x$ & $x$ & $x$ & $x$ \\
\hline \multicolumn{2}{|c|}{$\begin{array}{l}\text { Management of } \\
\text { pacing and time } \\
\text { allocation }\end{array}$} & $x$ & & & $x$ & $x$ \\
\hline \multicolumn{2}{|c|}{$\begin{array}{c}\text { Adaptation to } \\
\text { students' level and } \\
\text { profile }\end{array}$} & $x$ & & $x$ & $x$ & \\
\hline \multicolumn{2}{|c|}{$\begin{array}{c}\text { Teacher's } \\
\text { characteristics }\end{array}$} & $x$ & $x$ & $x$ & $x$ & $x$ \\
\hline
\end{tabular}

Table 4. Characteristics of the effective teacher identified in the synthesis of research into effective teaching in primary and secondary education, research into student evaluation of instruction and this study.

Firstly, we can see that the four actions commented on most frequently by students (clarity of presentation, learning management, activities and selection and structuring of content), as well as the teacher's characteristics, are included in all the studies presented in Table 4. Other authors such as Zimmaro, Gaede, Heikes, Shim, and Lewis (2006) have also shown that students' comments focus on clarity of presentation and the selection and structuring of content. Bernard (2011) showed that in general, student's comments relate to the clarity of the teacher's presentation, evaluation methods 
and teaching materials. The importance of the categories "clarity of presentation" and "selection and structuring of content" may indicate that students are focused on a transmissive model of teaching, as Le Duc, Dillenbourg, and Ricci (2012: 10) show.

Secondly, some of the teacher's actions are commented on less (if at all) and therefore do not seem to be defining characteristics of effective teaching, according to the students in our sample. This is the case with communication skills, adaptation to students' level and profile, management of working atmosphere and space, preparation and body language. However, as Table 4 shows, the importance of preparation was cited both in research into primary and secondary education and in several studies on the evaluation of teaching by students.

It is interesting to note that the importance of the management of working atmosphere and space and of body language was not cited in studies of student evaluation of instruction, whereas it was cited in studies of effective teaching in primary and secondary education. Regarding the relative lack of references to the management of working atmosphere and space, a hypothesis can be put forward: students probably do not regard this action on the part of the teacher as decisive in higher education, as it may be supposed that, confronted with an adult audience, the teacher has less need to manage discipline, students' movements, etc., than in primary and secondary education, although some students do refer to these discipline problems in our corpus. Moreover, the fact that students are relatively insensitive to the teacher's body language could be explained by the fact that certain relatively lecturercentred modes of education limit the possibilities of movement.

Finally, it is important to remain that these content analysis results have been mostly related to effectiveness models based on studies from primary and secondary education levels. Yet, higher education undoubtedly has its own characteristics such as largegroup instruction (Daele and Sylvestre, 2013; Morton, 2009). Our literature review shows the necessity to lead further research regarding effective teaching in higher education as they are currently very rare (Bedin and Broussal, 2012). Studies on actual university teaching (Alava, Clanet, and Trinquet, 1999) and their effectiveness, as well as studies making links between those and students' comments in the student evaluation of instruction should be encouraged.

\section{Conclusion and future prospects}

In this article, we have attempted to infer the characteristics of the effective teacher from comments made by students in answer to the question "What points could be improved?" The evaluation questionnaire results from a consensus between all the faculties of the University of Mons and is thus certainly perfectible. It would be interesting to continue this research by giving students a questionnaire with open questions explicitly asking them to identify the characteristics of the effective teacher (Allan, Clarke, and Jopling, 2009; Delaney, Johnson, Johnson, and Treslan, 2010). Indeed, more precise open questions can help students to structure their comments (Lewis, 2001).

Moreover, additional analyses will be performed using the content analysis software QDA Miner®, which allows coding sequences to be identified (Derobertmasure and Robertson, 2013). This software feature "allows the analyst to grasp the structure of the corpus being analysed by giving statistical information regarding the way in which the codes follow one another" (Derobertmasure and Robertson, 2013: 2261). In this study, it would be interesting to see to what extent the description of a teacher's action is followed by the description of the effect of this action. For example, here is a comment in which the description of a teacher's action (selection and structuring of content) is followed by the description of its effect on students' understanding: "The lecture is given before the practical [selection and structuring of content] which puts students at a serious disadvantage because it is easier to understand after you have already done a certain amount of programming [understanding]." Highlighting links between actions and their effects would improve the study of the characteristics of an effective teacher by answering the following question: what are the teacher's actions which, according to students, promote learning? Results presented in this article show that students' evaluations of teaching do make sense and students' open comments are mostly relevant. Next step is to convince higher education teachers of the interest of these comments in helping them to improve the quality of teaching and learning. Indeed some research have highlighted the fact that academics perceive such evaluation process as regulating tool menacing the principle of academic freedom (Younès, 2007b) rather than as a professional development tool. It is thus important for higher education institutions to put this myth down by showing that, as it is the case in this research, students mostly focus on teaching actions (instruction and class management) rather than on personal characteristics. However, few institutions provide sufficient support to teachers to help them read the results of the evaluations (Penny, 2003). In this perspective, the Pedagogic Support Service of the University of Mons intends to improve the way teachers get their results but also, based on this research, to give them means of interpreting received comments. Students' comments are a rich source of information, which, combined with other types of information (e.g. examination results, opinions of colleagues, selfevaluation), may encourage teachers to engage in a process of reflective practice and professional development (Berthiaume, Lanarès, Jacqmot, Winer, and Rochat, 2011) which could ultimately enable them to improve the effectiveness of their teaching.

If these research results are to be practically useful to improve teaching, it should be stressed that their validity and reliability have not been proved. In the next future, in order to attest our results as being significative, we will compare students' answers with other information provided by teachers or by direct observation and check them not only on an individual point of view, like here, but regarding particular teachers in order to measure the coherence of their profile.

Finally, presented results do not take into account, the position of the students in their educational programme (Bachelors or Masters). However, a previous study (Kozlowski, Artus, Derobertmasure, and Demeuse, 2014) revealed that the comments of Master students are 
longer than those of Bachelor students. Possible discrepancies should thus be studied by analyzing comments attributed to students according to their educational level as their representations, expectancies or experience can be variables to be taken into account in the possible fluctuating content of their comments.

\section{References}

Abrami, Philip.C., d'Apollonia, Sylvia, and Rosenfield, Steven. "The dimensionality of student ratings of instruction: what we know and what we do not." The Scholarship of Teaching and Learning in Higher Education: An Evidence-Based Perspective. Ed. Raymond P. Perry and John C. Smart. New York: Springer, 2007. 385-456. Web. 25 July 2014. http://dx.doi.org/10.1007/1-4020-5742-3_10

Alava, Séraphin, Clanet, Joël, \& Trinquier, Marie-Pierre. "Hétérogénéité et réussite dans le premier cycle universitaire. Conditions perçues et effectives des pratiques d'études et d'enseignement.“ Rapport de Recherche pour le Comité National de Coordination de la Recherche en Education (1999). Paris: INRP. Web. 16 december 2014. http://www.cdsauwb.be/www.cds

auwb.be/uploads/file_RAPPORT_Trinquier_CNCRE. pdf

Allan, Jo, Clarke, Karen, and Jopling, Michael. "Effective Teaching in Higher Education: Perceptions of First Year Undergraduate Students." International Journal of Teaching and Learning in Higher Education 21.3 (2009): 362-372. Web. 25 July 2014.

Aleamoni, Lawrence M. "Student Rating Myths Versus Research Facts from 1924 to 1998." Journal of Personnel Evaluation in Education 13.2 (1999): 153166. Web. 25 July. 2014. http://dx.doi.org/10.1023/A:1008168421283

Alhija, Fadia Nasser-Abu, and Fresko, Barbara. "Student evaluation of instruction: what can be learned from students' written comments?" Studies in Educational Evaluation 35 (2009): 37-44. Web. 25 July 2014. http://dx.doi.org/10.1016/j.stueduc.2009.01.002

Bardin, Laurence. L'analyse de contenu. 10th ed. Paris: Presses Universitaires de France, 2001. Print.

Bedin, Véronique, and Broussal, Dominique. "Place et opportunité des travaux sur l'effet maître dans les recherches en pédagogie universitaire." Questions vives 6.18 (2012): 111-128. Web. 25 July 2014. DOI : $10.4000 /$ questionsvives. 1170

Bernard, Huguette. Comment évaluer, améliorer, valoriser l'enseignement supérieur ? Bruxelles : De Boeck, 2011. Print.

Berthiaume, Denis, Lanarès, Jacques, Jacqmot, Christine, Winer, Laura \& Rochat, Jean-Moïse. "L'évaluation des enseignements par les étudiants (EEE). Une stratégie de soutien au développement pédagogique des enseignants ?" Recherche et formation 67 (2011): 53-72. Print.

Bissonnette, Steve, Richard, Mario, and Gauthier, Clermont. "Interventions pédagogiques efficaces et réussite scolaire des élèves provenant de milieux défavorisés." Revue française de pédagogie 150 (2005): 87-141. Print. http://dx.doi.org/10.3406/rfp.2005.3229

Bissonnette, Steve, Richard, Mario, and Gauthier, Clermont. Comment enseigne-t-on dans les écoles efficaces ? Laval : Les Presses de l'Université Laval, 2006. Print.

Bressoux, Pascal. "Réflexions sur l'effet-maître et l'étude des pratiques enseignantes." Les dossiers des Sciences de l'Education 5 (2001): 35-52. Print.

Creemers, Bert P.M. The effective classroom. London : Cassell, 1994. Print.

Creemers, Bert P.M, and Kyriakides, Leonidas. The dynamics of educational effectiveness. New York: Routledge, 2008. Print.

Daele, Amaury, and Sylvestre, Emmanuel. "Comment dynamiser un enseignement avec de grands effectifs?“. La pédagogie de l'enseignement supérieur: repères théoriques et applications pratiques. Ed. Denis Berthiaume and Nicole Rege Colet. Berne: Peter Lang, 2013. 149-164. Print.

Delaney, Jerome, Johnson, Albert, Johnson, Trudi, and Treslan, Dennis. Students' Perceptions of Effective Teaching in Higher Education. St. John's, NL: Distance Education and Learning Technologies, 2010. Web. 18 July 2014. <http://www.uwex.edu/disted/conference/Resource library/handouts/28251_10H.pdf>

Derobertmasure, Antoine, and Dehon, Arnaud. "Développement de la réflexivité et décodage de l'action : questions de méthode." Phronesis 1.2 (2012): 24-44. Web. 25 July 2014. http://dx.doi.org/10.7202/031894ar

Derobertmasure, Antoine, and Robertson, Jean E. “Data analysis in the context of teacher training: code sequence analysis using QDA MINER." Quality and quantity 48.4 (2013): 2255-2276. Web. 25 july $2014 . \quad$ http://dx.doi.org/10.1007/s11135-0139890-9

Ellett, Chad D., and Teddlie, Charles. "Teacher Evaluation, Teacher Effectiveness and School Effectiveness : Perspectives from the USA." Journal of Personnel Evaluation in Education 17.1 (2003): 101128. Web. 25 July 2014. http://dx.doi.org/10.1023/A:1025083214622

Gage, Nathaniel L. A Conception of Teaching. New York: Springer Science, 2009.2 Print. http://dx.doi.org/10.1007/978-0-387-09446-5

Gauthier, Clermont, Bisonnette, Steve, and Richard, Mario. Enseignement explicite et réussite des élèves. Bruxelles : De Boeck, 2013. Print.

Good, Thomas. L., and Brophy, Jere E. Looking in classrooms. Boston: Pearson Education, 2008. Print.

Kember, David \& Leung, Doris Y.P. "Disciplinary Differences in Student Ratings of Teaching Quality." Research in Higher Education, 52.3 (2011). Web. 18 december 2014. DOI : 10.1007/s11162-010-9194-z

Kozlowski, Dorothée, Artus, Frédérique, Derobertmasure, Antoine, and Demeuse, Marc. "Évaluation des enseignements par les étudiants. Modélisation des réponses aux questions ouvertes dans le cadre de l'évaluation pédagogique annuelle de l'Université de Mons (Belgique)." 26ème colloque de l'ADMEEEurope, Cultures et politiques de l'évaluation en éducation et en formation. Marrakech, 15-17 January 2014

Le Duc, Ingrid, Dillenbourg, Pierre, and Ricci, Jean-Louis. L'analyse des commentaires des étudiants dans les évaluations de l'enseignement montre qu'ils sont plus sensibles au fond qu'à la forme. 14-18 May 
2012, Trois-Rivières (Québec), 27e congrès de l'Association internationale de Pédagogie universitaire, Quelle université pour demain ? Web. $25 \quad$ july 2014. <https://oraprdnt.uqtr.uquebec.ca/pls/public/docs/ GSC2220/F1828181615_Programme_complet_et_a ctes_Affiches_et_communications_individuelles_Se ssion_1_6_Version_finale.pdf>

Lewis, Karron G. "Making Sense of Student Written Comments" New directions for teaching and learning, Techniques and Strategies for Interpreting Student Evaluations 87 (2001): 25-32. Print.

Marsh, Herbert W. 'Students' Evaluations of University Teaching: research Findings, Methodological Issues, and Directions for Future Research. A summary of the monograph by Marsh, H.W. (1987)" International Journal of Educational Research 11 (1987): 253387. Print. http://dx.doi.org/10.1016/08830355(87)90001-2

Merle, Pierre. "L'efficacité de l'enseignement." Revue française de sociologie 39.3 (1998): 565-589. Print. http://dx.doi.org/10.2307/3322985

Miles, Matthew B., and Huberman, A. Michael. Analyse des données qualitatives. 2d ed. Bruxelles: De Boeck, 2003. Print.

Mucchielli, Roger. L'analyse des documents et des communications. 9th ed. Issy-Les-Moulineaux: ESF, 2006. Print.

Mukamurera, Joséphine, Lacourse, France, and Couturier, Yves. "Des avancées en analyse qualitative: pour une transparence et une systématisation des pratiques". Recherches qualitatives 26.1 (2006): 110-138. Print.

Morton, Ann. "Lecturing to large groups“. Teaching and Learning in Higher Education. Ed. Heather Fry, Steve Ketteridge and Stephanie Marshall, New York: Routledge, 2009. 58-71. Print.

Penny, Angela R. "Changing the Agenda for Research into Students' Views about University Teaching: Four shortcomings of SRT research." Teaching in Higher $\begin{array}{llll}\text { Education } & 8.3 \quad \text { (2003): } & 399-411 .\end{array}$ http://dx.doi.org/10.1080/13562510309396

Prégent, Richard, Bernard, Huguette, and Kozanitis, Anastassis. Enseigner à l'université dans une approche programme. Québec: Presses internationales Polytechnique, 2009. Print.

Ramsden, Paul. Learning to teach in Higher Education. $2 d$ ed. New York : RoutledgeFalmer, 2003. Print.

Reynolds, David, Muijs, Daniel, and Treharne, David. "Teacher Evaluation and Teacher Effectiveness in the United Kingdom." Journal of Personnel Evaluation in Education 17.1 (2003): 83-100. Web 25 july 2014. http://dx.doi.org/10.1023/A:1025031130552

Rivkin, Steven G., Hanushek, Eric A. \& Kain, John F. "Teachers, schools and academic achievement." Econometrica 73.2 (2005): 417-458. Web. 25 july 2014. 0262.2005.00584.x

http://dx.doi.org/10.1111/j.1468-

Romainville, Marc. "Une expérience d'élaboration collective de critères de qualité." L'évaluation de l'enseignement par les étudiants. Approches critiques et pratiques innovantes. Ed. Marc Romainville and Cristina Coggi. Bruxelles: De Boeck, 2009. 145-163. Print.

Rosenshine, Barak. "Advances in Research on
Instruction". Issues in educating students with disabilities. Ed. J.W. Lloyd, E.J. Kameanui \& D. Chard. Mahwah, N.J.: Lawrence Erlbaum, 1997. 197-221. Print.

Scheerens, Jaap, and Bosker, Roel. The foundations of educational effectiveness. Oxford: Elsevier Science, 1997. Print.

Slavin, Robert E. Educational Psychology: Theory and practice. 9th ed. Boston: Pearson Education, 2009. Print.

Slavin, R.E. A model of Effective Instruction. Baltimore: Johns Hopkins University. Web. 18 July 2014. <http://www.successforall.org/SuccessForAll/media/ PDFs/modeleffect.htm>

Stronge, James H. Qualities of effective teachers. Alexandria: Association for Supervision and Curriculum Development, 2007. Print.

Teddlie, Charles \& Reynolds, David. The International Handbook of School Effectiveness Research. New York: Routledge, 2000. Print.

Wachtel, Howard K. "Student Evaluation of College Teaching Effectiveness: a brief review." Assessment \& Evaluation in Higher Education 23.2 (1998): 191212. Web. 25 July 2014. http://dx.doi.org/10.1080/0260293980230207

Wang, Margaret, Haertel, Geneva \& Walberg, Herbert. "Qu'est-ce qui aide l'élève à apprendre?" Vie pédagogique 90 (1994): 45-49. Print.

Winer, Laura, Di Genova, Lina, Vungoc, Pierre-Andre \& Talsma, Stephanie. Interpreting end-of-course evaluation results. Montreal: Teaching and Learning Services, McGill University, 2012. Web. 23 July 2014. <http://www.mcgill.ca/tls/sites/mcgill.ca.tls/files/co urse_evaluation_results_interpretation_guidelines_2. pdf>

Younès, Nathalie. L'effet-seuil de l'évaluation de l'enseignement supérieur par les étudiants. 28-31 Augustus 2007, Strasbourg (France), Congrès AREF. Web. 25 July 2014. <http://www.congresintaref.org/actes_pdf/AREF200 7_Nathalie_YOUNES_347.pdf>

Younès, Nathalie. "A quelles conditions l'évaluation formative de l'enseignement par les étudiants estelle possible en France ?" Revue Française de $\begin{array}{llll}P e ́ d a g o g i e & & \text { (2007): 25-40. Print. }\end{array}$ http://dx.doi.org/10.4000/rfp.800

Young, Suzanne, \& Shaw, Dale G. "Profile of effective college and university teachers." Journal of Higher Education $\quad 70 \quad$ (1999): $670-686$. http://dx.doi.org/10.2307/2649170

Zimmaro, Dawn M., Gaede, Charles S., Heikes, E. Joel, Shim, Mi-Suk P. \& Lewis, Karron G. A study of students' written course evaluation comments at a public university. Austin: University of Texas, 2006. Web $23 \quad$ July 2014. <http://ctl.utexas.edu/sites/default/files/cis_forms/ A-Study-of-Students-Written-Course-EvaluationComments-at-a-Public-University-2006.pdf> 
Autumn (July-December 2015) N. 15. Pages. 11

I How to cite this article:

Bocquillon, Marie, Antoine Derobertmasure, Frédérique Artus, y Marc Demeuse. “Students' comments about university teaching: which links with effectiveness models?" @tic. revista d'innovació educativa. 15. 2015: 1-11. 